One of the main drought avoidance strat-

\title{
Drought Avoidance Traits in a Collection of Zoysiagrasses
}

\author{
David Jespersen ${ }^{1}$ \\ University of Georgia, Department of Crop and Soil Sciences, 1109 \\ Experiment Street, Griffin, GA 30223 \\ Brian Schwartz \\ University of Georgia, Department of Crop and Soil Sciences, 2360 \\ Rainwater Road, Tifton, GA 31793
}

Additional index words. zoysiagrass, drought, rooting, conductance

\begin{abstract}
Drought avoidance is dictated by a collection of traits used to maintain tissue hydration levels and turgidity during water-limited conditions. These traits include deeper and more extensive rooting and the closure of stomata to limit the transpiration of water from leaves. Zoysiagrasses are a group of warm-season turfgrasses, including Zoysia japonica and Zoysia matrella, that are valued for their turfgrass quality; however, they are susceptible to drought relative to other warm-season turfgrass species. The objectives of the study were to determine 1) differences in drought avoidance among a collection of zoysiagrasses and 2) which drought avoidance traits contributed to these differences. Fifteen zoysiagrass genotypes were exposed to either drought or control conditions in a greenhouse environment. Overall performance was assessed by evaluating turfgrass quality and percentage green cover. Drought avoidance was estimated by measuring leaf hydration levels and drought avoidance traits [including stomatal conductance $\left.\left(g_{S}\right)\right]$; root traits such as total root biomass, specific root length (SRL), and root length density (RLD) were measured. Compared with commercial cultivars Meyer, Palisades, or Zeon, some experimental genotypes maintained greater turfgrass quality during drought, with experimental genotype '09-TZ-54-9' having a quality rating of 7.8 after 20 days of drought compared with 5.3 in 'Zeon', 5.2 in 'Meyer', and 5.0 in 'Palisades'. A range of belowground traits such as root biomass was also found to be associated with drought avoidance, with experimental ' $09-$ TZ-53-20' having 1.03 total grams, and 2.39 total grams in '10-TZ-1254', compared with 1.14, 1.66, and 3.44 total grams in 'Meyer', 'Zeon', and 'Palisades', respectively. Significant differences in drought avoidance were found among the 15 genotypes, with both belowground rooting traits and aboveground factors affecting transpiration influencing plant performance.
\end{abstract}

The genus Zoysia contains several important turfgrass species valued for their high turfgrass quality. These species include japanese lawngrass (Zoysia japonica S.), and manila grass (Zoysia matrella L.), which are able to form interspecific hybrids. Zoysiagrasses have been gaining popularity for use in southern latitudes, and development of new cultivars has increased in recent decades (Patton, 2009). Compared with other warmseason turfgrass species such as bermudagrass (Cynodon spp.) or st. augustinegrass (Stenotaphrum secundatum), zoysiagrasses are considered to have moderate to low levels of drought tolerance (Carrow, 1996b; Qian and Engelke, 1999; Wherley et al., 2014). As communities look to reduce irrigation inputs for landscape environments, there is a great desire to develop turfgrasses with improved drought performance that are able to withstand water-limited conditions.

Received for publication 25 July 2018. Accepted for publication 4 Sept. 2018.

Support for this work was provided by the University of Georgia Research Foundation.

${ }^{1}$ Corresponding author. E-mail: djesper@uga.edu.
Drought, resulting from limited plantavailable water, is one of the major abiotic stresses that limits performance in turfgrasses. Exposure to drought results in declining turfgrass quality resulting from wilting, leaf firing, dormancy, reduced canopy densities, and, ultimately, loss of plant stands (Carrow, 1996b). One of the most important ways plants can withstand waterlimited conditions and maintain quality is through drought avoidance. Drought avoidance is determined by a set of traits that allows a plant to maintain water uptake or reduce water loss during drought conditions, ultimately resulting in tissues that maintain hydration levels during these waterlimited periods (Ervin and Koski, 1998; Jones et al., 1981). Maintaining adequate tissue hydration despite challenging environmental conditions allows plants to maintain performance, including visual quality, and avoid the effects of dehydration, which include the production of reactive oxygen species, damage to photosynthetic pathways, and damage to cellular constituents such as membranes and proteins resulting from loss of cellular hydration (Carrow, 1996a; Huang et al., 2014). egies is to slow the consumption of soil water reserves and limit water loss through the leaf surface. Although evapotranspiration (ET) is driven by the environment, plants also have a role in regulating how much water is lost to the atmosphere (Colmer and Barton, 2017). This is largely accomplished through the closure of stomata, resulting in reduced transpiration from the leaf surface (Jones, 1998). Many factors influence $g_{S}$ and the closure of stomata, including plant signaling molecules and environmental cues such as abscisic acid, whole-plant hydraulic conductance, vapor pressure deficits, light and $\mathrm{CO}_{2}$, ions, and metabolites (Popova et al., 2000; Schroeder et al., 2001; Sperry et al., 2002; Wherley and Sinclair, 2009). Morphologic characteristics such as leaf width, orientation, and density or stomatal density also influence turfgrass ET (Anderson and Briske, 1990; Kim and Beard, 1988). Other morphologic changes such as leaf rolling can also reduce transpiration; however, leaf rolling typically occurs after leaf tissues are already stressed and bulliform cells have become dehydrated (O'Toole et al., 1979). Ultimately the size of stomatal aperture, density of stomata, as well as canopy characteristics such as leaf texture, length, and density all play important roles in regulating transpiration rates.

Rooting characteristics are another major aspect affecting drought avoidance. Through deeper or more extensive rooting, water may be extracted from a greater soil volume, allowing a plant to maintain water uptake despite drying of soils. Underground traits associated with plant performance during drought include fine roots, longer roots, and greater root densities, particularly at greater soil depths (Comas et al., 2013). Genetic variability for important root traits such as root length or density as they relate to drought have been identified in several important crops, including chickpea (Cicer arietinum L.) and rice (Oryza sativa L.), highlighting that genetic differences controlling belowground traits may influence drought performance (Gowda et al., 2011; Kashiwagi et al., 2005). Differences in important root characteristics such as rooting depth and root viability have been found to exist between turfgrass species with differing drought persistence in greenhouse trials (Huang et al., 1997). Similar root traits such as maximum depth and density were also found to correlate with drought avoidance under field conditions (Qian et al., 1997).

The goal of our experiment was to measure drought avoidance traits in a collection of zoysiagrasses subjected to water-limited conditions. Several studies have examined rooting traits (Carrow, 1996b; Christensen et al., 2017; Fuentealba et al., 2015; Marcum et al., 1995) and supplemental water requirements (Qian and Engelke, 1999; Wherley et al., 2014; White et al., 1993) as they relate to drought performance in zoysiagrasses, but there is a lack of research that looks at belowground root traits and aboveground drought avoidance traits (such as $g_{\mathrm{S}}$ ) 
integrated in a single study. We hypothesize that zoysiagrass genotypes that can use both extensive rooting and reduced transpiration through regulation of stomatal aperture will display the best drought performance. Understanding the interaction between aboveand belowground traits, the variation in the combination of avoidance traits, and potential tradeoffs of using specific traits are essential to advancing the physiology of drought avoidance. Determining the range of drought avoidance as well as differences in transpiration and rooting characteristics responsible for water uptake will help us to understand more fully the range of drought avoidance phenotypes in zoysiagrasses, as well as to understand more completely the mechanisms that may contribute to performance under water-limited conditions.

\section{Materials and Methods}

Plant materials and growth conditions. Two experiments were performed at the University of Georgia, Griffin Campus, in Fall 2017 and Winter 2018. A total of 15 genotypes, including Zoysia japonica cultivars Palisades, Meyer, and Zoysia matrella Zeon, as well as 12 experimental genotypes, consisting of both species and interspecific hybrids, were used in this study (Table 1). Plugs $(5 \mathrm{~cm})$ were washed free of soil, then roots were trimmed to $2 \mathrm{~cm}$ and transplanted into PVC pots that were $10 \mathrm{~cm}$ in diameter and $65 \mathrm{~cm}$ long, containing a fritted clay growing media (Profile products; Greens Grade, Buffalo Grove, IL). Plants were allowed to establish in a greenhouse for 10 weeks before the start of treatments. Plants were well watered, trimmed weekly to $5 \mathrm{~cm}$, and fertilized weekly with a 24-8-16 soluble fertilizer at $0.6 \mathrm{~g} \mathrm{~N} / \mathrm{m}^{2}$ (Scotts Miracle-Gro; Scotts, Marysville, $\mathrm{OH}$ ). Greenhouse conditions during establishment and experimental periods were set to $30 / 20{ }^{\circ} \mathrm{C}$ (maximum/ minimum) temperatures, and supplemental lighting was provided via $1000-\mathrm{W}$ highpressure sodium lamps set to a 12 -h photoperiod and set to provide supplemental lighting if natural lighting decreased to less than $400 \mu \mathrm{mol} \cdot \mathrm{m}^{-2} \cdot \mathrm{s}^{-1}$. Measured maximum and minimum greenhouse temperatures were 31.6 and $18.3{ }^{\circ} \mathrm{C}$, respectively, with an average relative humidity of $68 \%$ for the 2017 experiment. Measured maximum and minimum greenhouse temperatures were 28.9 and $16.7{ }^{\circ} \mathrm{C}$, respectively, with an average relative humidity of $56 \%$ for the 2018 experiment. After establishment, plants were exposed to drought treatments in which all water was withheld, or control conditions in which plants were well watered (watered three times weekly until drainage occurred from the bottom of the pots). Treatment conditions were maintained for $20 \mathrm{~d}$. Before the initiation of drought treatment, all pots were watered to field capacity. Soil volumetric water content was measured at the onset of treatments using a TRASE time domain reflectometry system (Soilmoisture Equipment, Goleta, CA).
Measurements. Overall performance was estimated by visual turfgrass quality ratings based on color, density, and uniformity on a scale of 1 to 9 , with 9 representing a healthy, dense green canopy; 1 being dead plants; and 6 being the minimum acceptable quality (Krans and Morris, 2007). Digital image

analysis was performed to assess percentage green cover using a digital camera (Canon G9X; Canon, Tokyo, Japan) and light box, which provided uniform lighting via lightemitting diodes. Images were analyzed using a custom macro in Image J V 1.5 (Schnell et al., 2009). Leaf hydration status was measured

Table 1. Details of zoysiagrass genotypes used in experiments.

\begin{tabular}{lll}
\hline Genotype & \multicolumn{1}{c}{ Species } & \multicolumn{1}{c}{ Source } \\
\hline $09-T Z-113$ & Zoysia japonica & Experimental breeding line \\
$09-T Z-53-20$ & Interspecific hybrid & Experimental breeding line \\
$09-\mathrm{TZ}-54-9$ & Interspecific hybrid & Experimental breeding line \\
$09-\mathrm{TZ}-89-73$ & Z. japonica & Experimental breeding line \\
$09-\mathrm{TZ}-98-30$ & Interspecific hybrid & Experimental breeding line \\
$10-\mathrm{TZ}-1254$ & Z. japonica & Experimental breeding line \\
$10-\mathrm{TZ}-3517$ & Z. japonica & Experimental breeding line \\
$15-\mathrm{TZ}-11261$ & Z. matrella & Experimental breeding line \\
$15-\mathrm{TZ}-11777$ & Z. matrella & Experimental breeding line \\
$29-2 \mathrm{~B} 7$ & Z. matrella & Experimental breeding line \\
DR-113 & Z. japonica & Experimental breeding line \\
DR-65 & Z. japonica & Experimental breeding line \\
Meyer & Z. japonica & U.S. Department of Agriculture, 1951 \\
Palisades & Z. japonica & Texas A\&M University, 1996 \\
Zeon & Z. matrella & Bladerunner Farms Inc., 1996 \\
\hline
\end{tabular}
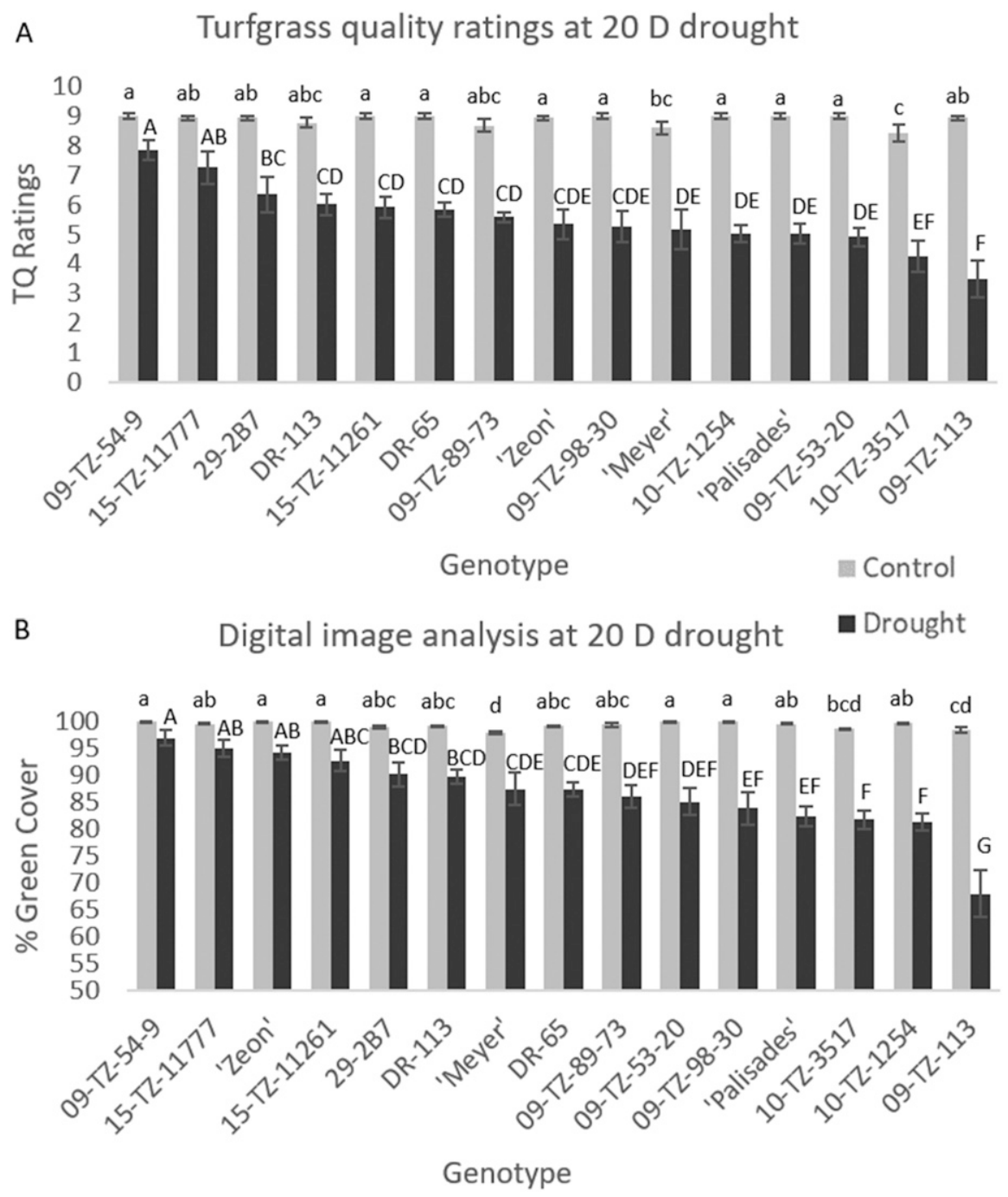

Fig. 1. Differences in (A) turfgrass quality (TQ) and (B) percentage green cover at $20 \mathrm{~d}$ of drought or control conditions among 15 zoysiagrass genotypes. Error bars represent SE. Genotypes with the same letter are not significantly different according to the least significant difference at $P \leq 0.05$ within a given treatment. 
via relative water content (RWC) using the methods described by Barrs and Weatherley (1962). About $0.2 \mathrm{~g}$ of fresh leaf tissue was harvested and weighed immediately to determine fresh weight, then soaked in deionized water overnight at $4{ }^{\circ} \mathrm{C}$. Leaves were then gently blotted dry and weighed again to determine turgid weight. Leaves were then dried in a $75-^{\circ} \mathrm{C}$ oven for $72 \mathrm{~h}$ and weighed again to determine dry weight. Calculation for RWC was (fresh weight - dry weight)/ (turgid weight - dry weight) $\times 100 \%=$ RWC.

Water use of different genotypes was determined gravimetrically. Before the start of stress treatments, pots were watered to field capacity. A balance was used to determine ET rates as well as cumulative water use for the duration of the experiment calculated gravimetrically, as the total sum of water lost from pots due to ET. Stomatal conductance was measured at the midpoint of the leaf on the adaxial side of three mature, fully expanded leaves per pot using a SC-1 leaf porometer (Meter Group, Pullman, WA). Data were collected during the same time of day (between 1100 and $1400 \mathrm{HR}$ ) on d 0, 3, 6, 13 , and 20 of each experiment. At the end of stress treatments $(20 \mathrm{~d})$ roots were washed free of growing media, the maximum length of the deepest root was measured, and the roots were split into $15-\mathrm{cm}$ sections. Roots were imaged on a flatbed scanner and then dried in a $75-{ }^{\circ} \mathrm{C}$ oven for $72 \mathrm{~h}$ to obtain dry weights. Root traits were estimated via the software Giaroots (Galkovskyi et al., 2012), and included average root width, root length, SRL (measured in meters per gram), RLD (measured in centimeters per cubic centimeter), and root distribution (percentage of roots in the upper $50 \%$ of the root zone based on dry weight). Leaf characteristics including stomata size (including guard cells) as well as stomatal density were measured on at least eight representative leaves of each genotype for plants growing under well-watered control conditions based on the methods of Hilu and Randall (1984). Images were acquired using a compound microscope (BX51; Olympus, Tokyo Japan) and analyzed using Image J software.

Data analysis. The experiment was arranged in a randomized complete block design with three replicates, and the entire experiment was repeated. All data were subject to analysis of variance with a mixed model, having the fixed effects of genotype and treatment (drought or well watered), and block and experimental run were random effects-analyzed using SAS JMP (version 13.2; SAS Institute, Cary, NC). Means were separated using Fisher's protected least significant difference $(P=0.05)$. Multivariate analysis included correlation analysis and partial least-squares regression. Partial leastsquares regression was performed using the nonlinear iterative partial least squares method, and three factors were used based on the results of the van der Voet test. Traits that exceeded 1.0 on variable importance projections were considered to be the greatest contributors to the model.

\section{Results}

Twenty days after initiation of drought stress, significant differences among genotypes were found relating to overall performance and drought avoidance traits. Soil water content declined to a minimum of $10 \%$ volumetric water content (VWC) during drought treatment, whereas control pots were maintained around $35 \%$ VWC. Under well-watered conditions, all plants maintained high quality and leaf hydration levels. Visual quality ratings and percentage green cover demonstrated a range of responses to soil drying, with experimental breeding lines representing both the best and worst performers (Fig. 1). Average turfgrass quality ratings ranged from 7.8 for '09-TZ54-9' to 3.5 for ' $09-T Z-113$ ' on the final day of drought stress, and percentage green cover ranged from $96.7 \%$ to $67.9 \%$ for ' $09-T Z-54-9$ ' and '09-TZ-113', which were, respectively, the best- and worst-performing lines on these measures. All genotypes maintained adequate turfgrass quality and green cover during control conditions. Values for RWC ranged from $84.9 \%$ to $68.2 \%$ on the final day of drought stress, demonstrating a range of leaf hydration levels resulting from drought avoidance (Fig. 2). The top statistical grouping for leaf RWC contained '15-TZ-11777', 'DR-113', 'Meyer', and '09-TZ-54-9', whereas the grouping of the poorest performers contained 'Palisades', 'Zeon', '09-TZ-53-20', and '09-TZ113'. Under well-watered conditions, RWC ranged from $96.2 \%$ to $90.0 \%$ with ' $29-2 \mathrm{~B} 7$ ', 'Meyer', and 'Zeon' being in the lowest statistical group.

Differences in leaf characteristics such as leaf width, stomatal size, and stomatal density were found among genotypes under control conditions (Table 2); however, there was no clear relationship among these traits and overall drought performance. Stomatal conductance decreased as a result of drought treatment, with many genotypes experiencing a rapid decrease in conductance (Table 3). At $13 \mathrm{~d}$ of drought treatment, many top-performing lines that were able to maintain leaf hydration levels, such as 'DR-113' or '09-TZ-11777', had significantly greater $g_{\mathrm{S}}$ values than poorer performing lines such as '09-TZ-113', which had $g_{\mathrm{S}}$ values of $152.3,126.1$, and $70.9 \mu \mathrm{mol} \mathrm{H}_{2} \mathrm{O} / \mathrm{mm}^{2} / \mathrm{s}$, respectively. Similarly, ET rates also decreased as a result of drought treatment (Table 4). The best-performing lines, which

A

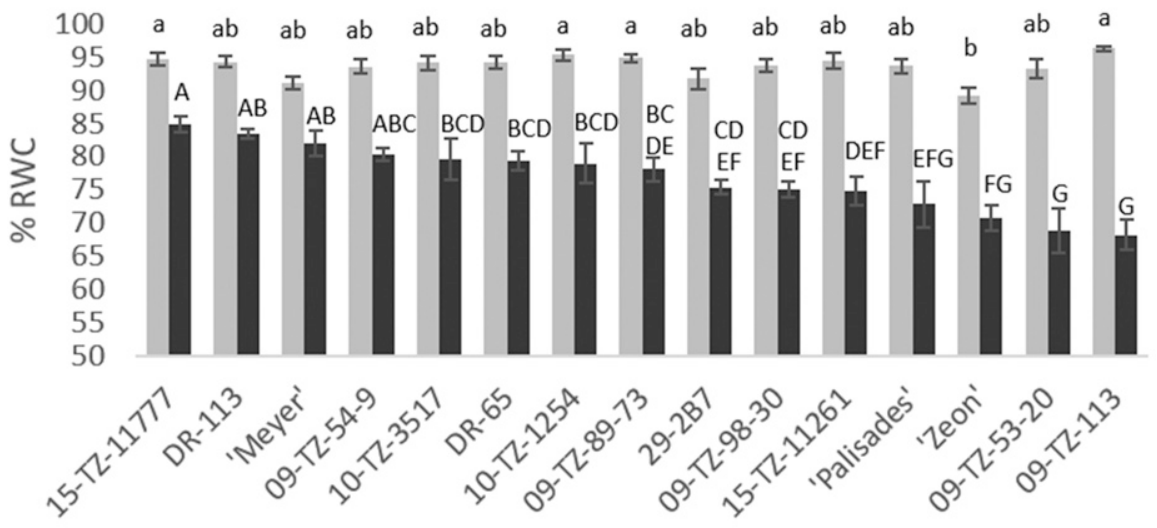

B Leaf water content at $20 \mathrm{D}$ drought Cumulative Water Use Control

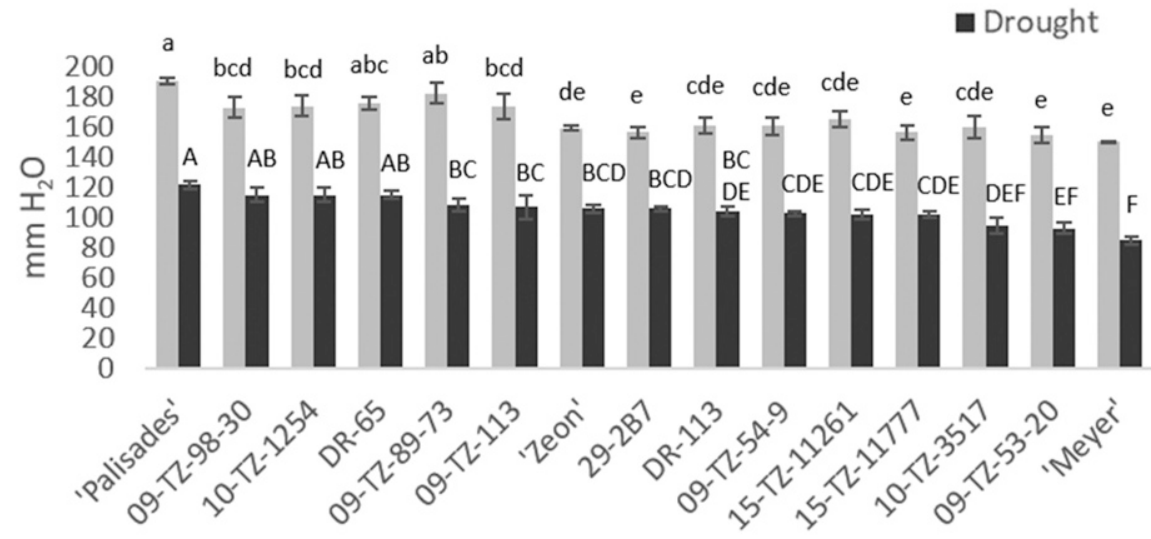

\section{Genotype}

Fig. 2. Differences in (A) relative water content and (B) cumulative water use content at $20 \mathrm{~d}$ of drought or control conditions among 15 zoysiagrass genotypes. Error bars represent SE. Genotypes with the same letter are not significantly different according to the least significant difference at $P \leq 0.05$ within a given treatment. $\mathrm{RWC}=$ relative water content. 
had greater $g_{\mathrm{S}}$ values during the latter periods of drought, generally had greater reductions in ET rates during the beginning of drought treatment compared with well-watered controls, but generally had greater relative ET rates at the end of drought when presented as a percentage of well-watered control plants - perhaps indicating a more conservative use of water to save resources as the stress period continued. These differences in $g_{\mathrm{S}}$ values and ET rates resulted in significant differences in cumulative water loss during drought, ranging from $85.2 \mathrm{~mm}$ over the 20 - $\mathrm{d}$ period in 'Meyer' to $121.7 \mathrm{~mm}$ in 'Palisades' (Fig. 2).

Significant differences in rooting characteristics were also found among cultivars for measured traits, including total root dry weight, average root width, percent of roots distributed in the upper $50 \%$ of the root zone, SRL, RLD, and root length (Table 5). The total amount of roots based on dry weight ranged from $3.44 \mathrm{~g}$ in 'Palisades to $1.03 \mathrm{~g}$ in '09-TZ-53-20'. A range in RLD from 3.95 $\mathrm{cm} \cdot \mathrm{cm}^{-3}$ in 'DR-65' to $1.28 \mathrm{~cm} \cdot \mathrm{cm}^{-3}$ in
' $10-\mathrm{TZ}-3517$ ' was found, demonstrating differences in belowground traits and extensiveness of root systems in zoysiagrasses. Correlation analysis was performed to understand more fully the relationships between rooting traits and cumulative water use (Table 6). Correlation coefficients of 0.82 were found between cumulative water use and total root weight. Correlations were also found between related rooting traits such as total root weight and RLD (0.63), and average root width and SRL $(-0.83)$, as expected. As a result of the interrelatedness of many traits, such as $g_{\mathrm{S}}$ and ET, or total root weight and RLD, partial least-squares regression was used to determine which factors may contribute the greatest to the variation in RWC found among genotypes. Based on the van der Voet $\mathrm{T}^{2}$, the analysis was run with three factors, for which the model explained $53 \%$ of the variation in RWC. Using a variable importance threshold of 1.0 , ET, $g_{\mathrm{S}}$, total root weight, and RLD were determined to be the greatest predictors of RWC at the end of drought based on the model, with ET $(20 \mathrm{~d})$ and $g_{\mathrm{S}}(13 \mathrm{~d}$ and $20 \mathrm{~d})$ having the highest variable importance scores at the end of drought (Fig. 3).

\section{Discussion}

A wide range of drought avoidance was found among the genotypes screened for RWC, which measures directly a plant's ability to maintain leaf hydration status. Several genotypes were consistently in the top statistical groups and maintained greater visual quality and greater levels of leaf water content throughout the course of drought in this study. These genotypes included '15-TZ11777' and '09-TZ-54-9'. On the other end of the spectrum, '09-TZ-53-20' and '09-TZ113 ' were consistently the lowest performing in terms of drought avoidance. These results demonstrate there is a range of drought avoidance traits within zoysiagrass species that can be integrated into new cultivars to improve drought performance. Several traits relating to drought avoidance, including $g_{\mathrm{S}}$ and ET rates, were measured for

Table 2. Leaf characteristics of 15 zoysiagrass genotypes. Measurements included average leaf width, stomata size, and density \pm sD.

\begin{tabular}{|c|c|c|c|c|c|}
\hline \multirow[b]{2}{*}{ Genotype } & \multirow[b]{2}{*}{ Leaf width (mm) } & \multicolumn{2}{|c|}{ Stomata size $\left(\mu \mathrm{m}^{2}\right)$} & \multicolumn{2}{|c|}{ Stomatal density $\left(\right.$ no. $\left./ \mathrm{mm}^{2}\right)$} \\
\hline & & $\mathrm{AD}$ & $\mathrm{AB}$ & $\mathrm{AD}$ & $\mathrm{AB}$ \\
\hline 09-TZ-113 & $4.8 \pm 0.5$ & $236 \pm 27$ & $326 \pm 26$ & $294 \pm 40$ & $160 \pm 37$ \\
\hline $09-\mathrm{TZ}-53-20$ & $2.8 \pm 0.4$ & $140 \pm 37$ & $222 \pm 14$ & $484 \pm 120$ & $270 \pm 46$ \\
\hline 09-TZ-54-9 & $3.0 \pm 0.3$ & $153 \pm 25$ & $226 \pm 26$ & $476 \pm 44$ & $242 \pm 52$ \\
\hline 09-TZ-89-73 & $3.0 \pm 0.5$ & $156 \pm 30$ & $187 \pm 8$ & $366 \pm 33$ & $300 \pm 23$ \\
\hline 09-TZ-98-30 & $2.2 \pm 0.2$ & $147 \pm 14$ & $192 \pm 22$ & $452 \pm 52$ & $275 \pm 25$ \\
\hline 10-TZ-1254 & $3.4 \pm 0.4$ & $158 \pm 21$ & $230 \pm 12$ & $399 \pm 31$ & $260 \pm 26$ \\
\hline 10-TZ-3517 & $2.6 \pm 0.3$ & $146 \pm 15$ & $219 \pm 15$ & $449 \pm 52$ & $286 \pm 30$ \\
\hline 15-TZ-11261 & $2.2 \pm 0.3$ & $130 \pm 19$ & $205 \pm 18$ & $441 \pm 48$ & $260 \pm 19$ \\
\hline 15-TZ-11777 & $2.5 \pm 0.3$ & $132 \pm 19$ & $173 \pm 9$ & $446 \pm 124$ & $285 \pm 50$ \\
\hline $29-2 \mathrm{~B} 7$ & $2.3 \pm 0.2$ & $144 \pm 10$ & $216 \pm 18$ & $480 \pm 18$ & $263 \pm 37$ \\
\hline DR-113 & $3.5 \pm 0.8$ & $155 \pm 18$ & $193 \pm 13$ & $424 \pm 71$ & $318 \pm 34$ \\
\hline DR-65 & $3.8 \pm 0.5$ & $178 \pm 8$ & $197 \pm 9$ & $385 \pm 26$ & $308 \pm 40$ \\
\hline Meyer & $3.2 \pm 0.2$ & $191 \pm 19$ & $230 \pm 12$ & $426 \pm 69$ & $251 \pm 46$ \\
\hline Palisades & $4.1 \pm 0.6$ & $172 \pm 32$ & $212 \pm 16$ & $394 \pm 73$ & $324 \pm 14$ \\
\hline Zeon & $1.8 \pm 0.2$ & $139 \pm 11$ & $192 \pm 15$ & $519 \pm 13$ & $259 \pm 20$ \\
\hline Significance & $* * *$ & $* * *$ & $* * *$ & $* *$ & $* * *$ \\
\hline $\operatorname{LSD}(P \leq 0.05)$ & 0.43 & 31 & 24 & 90 & 50 \\
\hline
\end{tabular}

*,**,***Significant at $P \leq 0.05,0.01$, or 0.001 , respectively.

$\mathrm{AD}=$ adaxial leaf surface; $\mathrm{AB}=$ abaxial leaf surface; $\mathrm{LSD}=$ least significant difference.

Table 3. Stomatal conductance of 15 zoysiagrass genotypes over $20 \mathrm{~d}$ of drought (expressed as micromoles of water per square millimeter per second).

\begin{tabular}{|c|c|c|c|c|c|}
\hline \multirow[b]{2}{*}{ Genotype } & \multicolumn{5}{|c|}{ Days of drought } \\
\hline & 0 & 3 & 6 & 13 & 20 \\
\hline 09-TZ-113 & 221.7 bcde & $187.4 \mathrm{ab}$ & $186.9 \mathrm{ab}$ & $70.9 \mathrm{~d}$ & $79.6 \mathrm{bc}$ \\
\hline $09-T Z-53-20$ & $184.8 \mathrm{e}$ & $89.8 \mathrm{~d}$ & $88.7 \mathrm{~g}$ & $63.9 \mathrm{~d}$ & $43.4 \mathrm{ef}$ \\
\hline 09-TZ-54-9 & $193.2 \mathrm{de}$ & $144.3 \mathrm{bcd}$ & 130.5 cdefg & $87.2 \mathrm{~cd}$ & $31.0 \mathrm{f}$ \\
\hline 09-TZ-89-73 & 232.7 bcde & $111.8 \mathrm{~cd}$ & 116.9 defg & $114.3 \mathrm{bcd}$ & $43.3 \mathrm{ef}$ \\
\hline 09-TZ-98-30 & $183.5 \mathrm{e}$ & $149.4 \mathrm{bcd}$ & 156.4 abcde & $114.0 \mathrm{bcd}$ & $74.7 \mathrm{bcd}$ \\
\hline 10-TZ-1254 & 230.7 bcde & $168.8 \mathrm{abc}$ & 151.3 bcdef & $110.1 \mathrm{bcd}$ & $85.3 \mathrm{bc}$ \\
\hline 10-TZ-3517 & $200.9 \mathrm{de}$ & $183.1 \mathrm{ab}$ & $101.4 \mathrm{fg}$ & $102.6 \mathrm{bcd}$ & 72.2 bcde \\
\hline 15-TZ-11261 & 239.1 bcde & $132.3 \mathrm{bcd}$ & 139.7 bcdefg & $87.1 \mathrm{~cd}$ & $45.8 \mathrm{def}$ \\
\hline 15-TZ-11777 & $268.6 \mathrm{abc}$ & $133.0 \mathrm{bcd}$ & 148.4 bcdef & $126.1 \mathrm{abc}$ & $56.8 \mathrm{cdef}$ \\
\hline $29-2 \mathrm{~B} 7$ & $278.2 \mathrm{ab}$ & $182.6 \mathrm{ab}$ & $171.8 \mathrm{abcd}$ & $129.2 \mathrm{abc}$ & $124.0 \mathrm{a}$ \\
\hline DR-113 & $330.0 \mathrm{a}$ & $192.8 \mathrm{ab}$ & $207.7 \mathrm{a}$ & $152.3 \mathrm{ab}$ & $58.4 \mathrm{cdef}$ \\
\hline DR-65 & $260.3 \mathrm{abcd}$ & $226.5 \mathrm{a}$ & $187.0 \mathrm{abc}$ & $170.3 \mathrm{a}$ & 67.3 bcde \\
\hline Meyer & 249.4 bcde & $151 \mathrm{bcd}$ & 134.8 bcdefg & $102.9 \mathrm{bcd}$ & $47.5 \mathrm{def}$ \\
\hline Palisades & 204.4 cde & $164.2 \mathrm{abc}$ & $115.8 \mathrm{efg}$ & $86.9 \mathrm{~cd}$ & $57.0 \mathrm{cdef}$ \\
\hline Zeon & 223.1 bcde & $157.1 \mathrm{bc}$ & $117.2 \mathrm{efg}$ & $99.4 \mathrm{bcd}$ & $113.7 \mathrm{ab}$ \\
\hline Significance & $* *$ & $*$ & $* * *$ & $*$ & $* * *$ \\
\hline CV $(\%)$ & 25.0 & 35.7 & 32.8 & 42.7 & 41.1 \\
\hline
\end{tabular}

$*, * *, * * *$ Significant at $P \leq 0.05,0.01$, or 0.001 , respectively.

Least significant difference (LSD) letters based on significant differences at $P \leq 0.05$. Genotypes with the same letter are not significantly different. $\mathrm{CV}=$ coefficient of variation. 
aboveground tissues, and root characteristics below ground to understand the differences found among genotypes.

Cumulative water use (total water lost during the drought period) and ET rates differed significantly among genotypes in this study, with genotypes that used water more slowly being the top performers. Fuentealba et al. (2016) found previously that transpiration rates and breakpoints at which transpiration declined based on soil water content differed among zoysiagrass genotypes. However, other studies have found that differences in ET rates among zoysiagrass cultivars only vary under certain environmental conditions, indicating that environment plays a large role in observed differences (Green et al., 1991). More rapid closing of stomata to limit water loss during drought has been proposed as an important mechanism for warm-season turfgrasses during long-term droughts (Cathey et al., 2013).
Decreased soil water availability and reduced transpiration may also affect photosynthesis rates and thereby overall turf performance, but more research is needed into the optimal balance of a plant conserving water and maintaining metabolic activity (Zhang et al., 2017).

Stomatal conductance was found to be one of the greatest predictors of RWC during drought in this study based on multiple regression methods, particularly during mid to late drought. '15-TZ-11777' and 'DR-113' both reduced $g_{\mathrm{S}}$ at the beginning of drought, compared with '09-TZ-113' or 'Palisades', which maintained $g_{\mathrm{S}}$ more similar to control conditions during this time period. This may indicate that rapid stomatal response is important to conserve water for longer term drought conditions. This is also reflected in ET rates, with '15-TZ-11777' having an ET rate of only $70 \%$ compared with wellwatered plants at $6 \mathrm{~d}$ of treatment, represent- ing one of the greatest reductions in ET rate. Furthermore, top-performing genotypes '15-TZ-11777', '09-TZ-54-09', and 'DR113 ' all had less-severe declines in ET rates at the end of the drought period, with percentage reductions in ET being 26\%, 31\%, and $37 \%$, respectively, compared with a $55 \%$ reduction in ET for the worstperforming '09-TZ-113' - perhaps indicating that a greater portion of transpirable soil water was still available for use in the topperforming genotypes. This corresponds with a general trend throughout the experiment that pots with greater cumulative water use had a lower RWC. Leaf characteristics such as stomatal density did not have an obvious impact on $g_{\mathrm{S}}$, which is similar to the results found by Green et al. (1991), and a more detailed analysis is needed to understand more fully how zoysiagrasses control transpirational water loss. Although $g_{\mathrm{S}}$ and ET rates were important factors in the partial

Table 4. Evapotranspiration (ET) rates over the course of drought among 15 zoysiagrass genotypes. ET rates are given for genotypes under both drought and watered nonstress conditions.

\begin{tabular}{|c|c|c|c|c|c|c|c|c|}
\hline \multirow[b]{3}{*}{ Genotype } & \multicolumn{8}{|c|}{ ET rates $\left(\mathrm{mm} \cdot \mathrm{d}^{-1}\right)$} \\
\hline & \multicolumn{2}{|c|}{$0-3 \mathrm{~d}$} & \multicolumn{2}{|c|}{$3-6 d$} & \multicolumn{2}{|c|}{$6-13 d$} & \multicolumn{2}{|c|}{$13-20 \mathrm{~d}$} \\
\hline & Control & Drought & Control & Drought & Control & Drought & Control & Drought \\
\hline 09-TZ-113 & $8.8 \mathrm{ab}$ & 8.8 abc & $9.0 \mathrm{abc}$ & $9.2 \mathrm{ab}$ & $9.0 \mathrm{abcd}$ & $6.1 \mathrm{abcd}^{\mathrm{z}}$ & $8.2 \mathrm{a}$ & $3.5 \mathrm{fg}^{\mathrm{z}}$ \\
\hline 09-TZ-53-20 & $7.5 \mathrm{~g}$ & $6.7 \mathrm{de}$ & $7.8 \mathrm{~cd}$ & $6.2 \mathrm{efg}$ & $7.8 \mathrm{cde}$ & $4.6 \mathrm{fgh}^{\mathrm{z}}$ & $7.7 \mathrm{cdef}$ & $3.5 \mathrm{fg}^{\mathrm{z}}$ \\
\hline 09-TZ-54-9 & 8.0 bcdef & $7.0 \mathrm{de}$ & $8.6 \mathrm{bcd}$ & $5.6 \mathrm{fg}^{\mathrm{z}}$ & 8.6 bcde & $5.3 \operatorname{cdefg}^{z}$ & $7.2 \mathrm{ef}$ & $4.3 \mathrm{abc}^{\mathrm{z}}$ \\
\hline 09-Tz-89-73 & $8.7 \mathrm{abc}$ & $8.9 \mathrm{abc}$ & $9.4 \mathrm{ab}$ & $6.6 \mathrm{ef}^{z}$ & $10.0 \mathrm{a}$ & $4.8 \mathrm{efgh}^{\mathrm{z}}$ & $8.3 \mathrm{abcd}$ & $4.2 \mathrm{abcd}^{\mathrm{z}}$ \\
\hline 09-Tz-98-30 & $9.0 \mathrm{a}$ & $8.9 \mathrm{abc}$ & $8.8 \mathrm{abc}$ & $8.1 \mathrm{bcd}$ & 8.9 abcd & $6.5 \mathrm{ab}^{\mathrm{z}}$ & $8.2 \mathrm{abcd}$ & 3.9 bcdef $^{z}$ \\
\hline $10-\mathrm{Tz}-1254$ & $8.5 \mathrm{abcd}$ & $9.4 \mathrm{ab}$ & $9.7 \mathrm{ab}$ & 7.5 cde & $9.2 \mathrm{abc}$ & $6.3 \mathrm{abc}^{\mathrm{z}}$ & $7.9 \mathrm{cdef}$ & $4.1 \mathrm{bcde}^{\mathrm{z}}$ \\
\hline $10-\mathrm{Tz}-3517$ & $7.5 \mathrm{f}$ & $8.0 \mathrm{bcd}$ & $8.5 \mathrm{bcd}$ & $6.7 \mathrm{def}^{\mathrm{z}}$ & 8.3 bcde & $4.9 \mathrm{defgh}^{\mathrm{z}}$ & $7.6 \mathrm{def}$ & 3.7 cdef $^{z}$ \\
\hline $15-\mathrm{Tz}-11261$ & $7.7 \mathrm{def}$ & $7.5 \mathrm{cde}$ & $8.6 \mathrm{bcd}$ & $6.2 \mathrm{efg}^{\mathrm{z}}$ & $8.7 \mathrm{abcd}$ & $4.5 \mathrm{gh}^{\mathrm{z}}$ & 7.9 cdef & $3.5 \mathrm{efg}^{\mathrm{z}}$ \\
\hline $15-\mathrm{Tz}-11777$ & $7.6 \mathrm{ef}$ & $6.3 \mathrm{e}^{\mathrm{z}}$ & $7.5 \mathrm{~cd}$ & $5.9 \mathrm{fg}$ & $7.2 \mathrm{e}$ & 5.6 abcdefg $^{\mathrm{z}}$ & 8.0 abcde & $4.7 \mathrm{a}^{\mathrm{z}}$ \\
\hline $29-2 \mathrm{~B} 7$ & $7.9 \mathrm{cdef}$ & $7.2 \mathrm{de}$ & $7.9 \mathrm{~cd}$ & $6.0 \mathrm{efg}^{\mathrm{z}}$ & $7.7 \mathrm{de}$ & 5.8 abcdef $^{z}$ & 7.9 cdef & $4.3 \mathrm{ab}^{\mathrm{z}}$ \\
\hline DR-113 & 8.4 abcde & $6.7 \mathrm{de}^{z}$ & $8.7 \mathrm{abcd}$ & $7.4 \mathrm{cde}$ & 8.5 bcde & $5.9 \mathrm{abcde}^{\mathrm{z}}$ & $7.1 \mathrm{f}$ & 3.8 bcdef $^{z}$ \\
\hline Dr-65 & $8.6 \mathrm{abc}$ & $7.6 \mathrm{cde}$ & $9.5 \mathrm{ab}$ & $8.2 \mathrm{bc}$ & $9.4 \mathrm{ab}$ & $6.6 \mathrm{ab}^{\mathrm{z}}$ & $7.9 \mathrm{abc}$ & $4.2 \mathrm{abcd}^{\mathrm{z}}$ \\
\hline Meyer & $7.4 \mathrm{f}$ & $7.2 \mathrm{de}$ & $7.3 \mathrm{~d}$ & $5.1 \mathrm{~g}^{\mathrm{z}}$ & $7.2 \mathrm{e}$ & $3.8 \mathrm{~h}^{\mathrm{z}}$ & 7.9 bcdef & $3.1 \mathrm{~g}^{\mathrm{z}}$ \\
\hline Palisades & $9.2 \mathrm{a}$ & $9.7 \mathrm{a}$ & $10.0 \mathrm{a}$ & $10.0 \mathrm{a}$ & $10.1 \mathrm{a}$ & $6.8 \mathrm{a}^{\mathrm{z}}$ & $8.8 \mathrm{ab}$ & $3.7 \mathrm{defg}^{\mathrm{z}}$ \\
\hline Zeon & $8.0 \mathrm{cdef}$ & 7.8 cde & $7.9 \mathrm{~cd}$ & $7.4 \mathrm{cde}$ & 7.9 cde & 5.5 bcdefg $^{z}$ & 8.1 abcde & 3.7 cdef $^{2}$ \\
\hline Significance & $* * *$ & $* * *$ & $*$ & $* * *$ & $* *$ & $* * *$ & $*$ & $* * *$ \\
\hline LSD & 0.8 & 1.5 & 1.4 & 1.5 & 1.4 & 1.2 & 1.1 & 0.6 \\
\hline
\end{tabular}

$*, * *, * *$ Significant at $P \leq 0.05,0.01$, or 0.001 , respectively

${ }^{\mathrm{z}}$ Significant differences between treatments for a given genotype on that sampling day $(P<0.05)$.

Least significant difference (LSD) letters based on significant differences at $P \leq 0.05$. Genotypes with the same letter are not significantly different. LSD values for comparisons between cultivars within a given treatment, $P<0.05$.

Table 5. Root traits of 15 zoysiagrass genotypes.

\begin{tabular}{|c|c|c|c|c|c|c|}
\hline Genotype & Root dry wt (g) & $\begin{array}{l}\text { Root distribution } \\
\text { (top } 50 \% \text { ) }\end{array}$ & Root width (mm) & $\operatorname{SRL}\left(\mathrm{m} \cdot \mathrm{g}^{-1}\right)$ & $\operatorname{RLD}\left(\mathrm{cm} \cdot \mathrm{cm}^{-3}\right)$ & Length $(\mathrm{cm})$ \\
\hline 09-TZ-113 & $1.54 \mathrm{def}$ & $61.8 \mathrm{fg}$ & $0.28 \mathrm{bcd}$ & 62.0 bcde & $1.89 \mathrm{de}$ & $57.2 \mathrm{abc}$ \\
\hline 09-TZ-53-20 & $1.03 \mathrm{f}$ & $88.5 \mathrm{a}$ & $0.269 \mathrm{cde}$ & 76 abcd & $1.51 \mathrm{e}$ & $47.4 \mathrm{e}$ \\
\hline 09-TZ-54-9 & $1.16 \mathrm{ef}$ & 75.8 bcde & $0.257 \mathrm{de}$ & $94.5 \mathrm{a}$ & $2.05 \mathrm{cde}$ & $53.1 \mathrm{bcde}$ \\
\hline 09-TZ-89-73 & $1.71 \mathrm{~cd}$ & $66.2 \mathrm{efg}$ & $0.267 \mathrm{cde}$ & $71.6 \mathrm{abcd}$ & 2.36 bcde & $60.3 \mathrm{a}$ \\
\hline 09-TZ-98-30 & $1.89 \mathrm{bcd}$ & $66.6 \mathrm{defg}$ & $0.280 \mathrm{bcd}$ & 66.5 abcde & 2.46 bcde & $54.6 \mathrm{abcd}$ \\
\hline 10-TZ-1254 & $2.39 \mathrm{~b}$ & $58.1 \mathrm{~g}$ & $0.262 \mathrm{de}$ & $77.8 \mathrm{abcd}$ & $3.35 \mathrm{abc}$ & $57.4 \mathrm{ab}$ \\
\hline 10-TZ-3517 & $1.66 \mathrm{de}$ & $79.5 \mathrm{ab}$ & $0.321 \mathrm{a}$ & $39.7 \mathrm{e}$ & $1.28 \mathrm{e}$ & $53.7 \mathrm{bcd}$ \\
\hline 15-TZ-11261 & $1.41 \mathrm{def}$ & $77.1 \mathrm{bc}$ & $0.311 \mathrm{ab}$ & 59.4 cde & $1.80 \mathrm{de}$ & 52.5 bcde \\
\hline 15-TZ-11777 & $1.91 \mathrm{bcd}$ & 75.6 bcde & $0.258 \mathrm{de}$ & $92.6 \mathrm{a}$ & $3.51 \mathrm{ab}$ & $54.8 \mathrm{abcd}$ \\
\hline $29-2 \mathrm{~B} 7$ & $1.74 \mathrm{~cd}$ & 68.7 cdef & $0.301 \mathrm{abc}$ & $55.3 \mathrm{de}$ & $1.83 \mathrm{de}$ & $53.7 \mathrm{bcd}$ \\
\hline DR-113 & $2.23 \mathrm{bc}$ & $63.6 \mathrm{fg}$ & 0.264 cde & $71.3 \mathrm{abcd}$ & $3.01 \mathrm{abcd}$ & $54.2 \mathrm{abcd}$ \\
\hline DR-65 & $2.32 \mathrm{~b}$ & $76.3 \mathrm{bcd}$ & $0.240 \mathrm{e}$ & $90.4 \mathrm{ab}$ & $3.95 \mathrm{a}$ & $51.0 \mathrm{cde}$ \\
\hline Meyer & $1.14 \mathrm{ef}$ & $78.2 \mathrm{bc}$ & $0.262 \mathrm{de}$ & $89.4 \mathrm{abc}$ & $1.77 \mathrm{de}$ & $50.4 \mathrm{de}$ \\
\hline Palisades & $3.44 \mathrm{a}$ & 67.2 defg & $0.263 \mathrm{de}$ & 61.2 bcde & $3.87 \mathrm{a}$ & $56.5 \mathrm{abcd}$ \\
\hline Zeon & $1.66 \mathrm{de}$ & $77.6 \mathrm{bc}$ & $0.268 \mathrm{cde}$ & 69.1 abcde & $2.02 \mathrm{de}$ & 51.9 bcde \\
\hline Significance & $* * *$ & $* * *$ & $* *$ & $*$ & $* * *$ & $*$ \\
\hline CV $(\%)$ & 25.8 & 11.8 & 11.6 & 36.8 & 47 & 10.2 \\
\hline
\end{tabular}

$*, * *, * * *$ Significant at $P \leq 0.05,0.01$, or 0.001 , respectively.

Least significant difference letters based on significant differences at $P \leq 0.05$. Genotypes with the same letter are not significantly different.

$\mathrm{SRL}=$ specific root length; $\mathrm{RLD}=$ root length density; $\mathrm{CV}=$ coefficient of variation. 
Table 6. Correlation coefficients between root traits and cumulative water use for 15 zoysiagrass genotypes during drought stress.

\begin{tabular}{lccccccc}
\hline & CWU & RT WT & DIST & WIDT & SRL & RLD & RT L \\
\hline CWU & - & & & & & & \\
RT WT & $0.82^{*}$ & - & $-0.49^{*}$ & - & & & \\
DIST & $0.56^{*}$ & -0.12 & 0.01 & 0.09 & - & & \\
WIDT & -0.12 & -0.23 & 0.09 & $-0.84^{*}$ & - & & \\
SRL & -0.06 & $0.63^{*}$ & $-0.41^{*}$ & $-0.63^{*}$ & $0.56^{*}$ & - & \\
RLD & $0.41^{*}$ & 0.22 & $-0.58^{*}$ & -0.07 & -0.05 & 0.16 & - \\
RT L & 0.07 & & & & &
\end{tabular}

*Significant at $P \leq 0.05$.

$\mathrm{CWU}=$ cumulative water use; RT WT $=$ root weight; DIST $=$ root distribution; WIDT $=$ average root width; $\mathrm{SRL}=$ specific root length; RLD = root length density; RT L = root length.
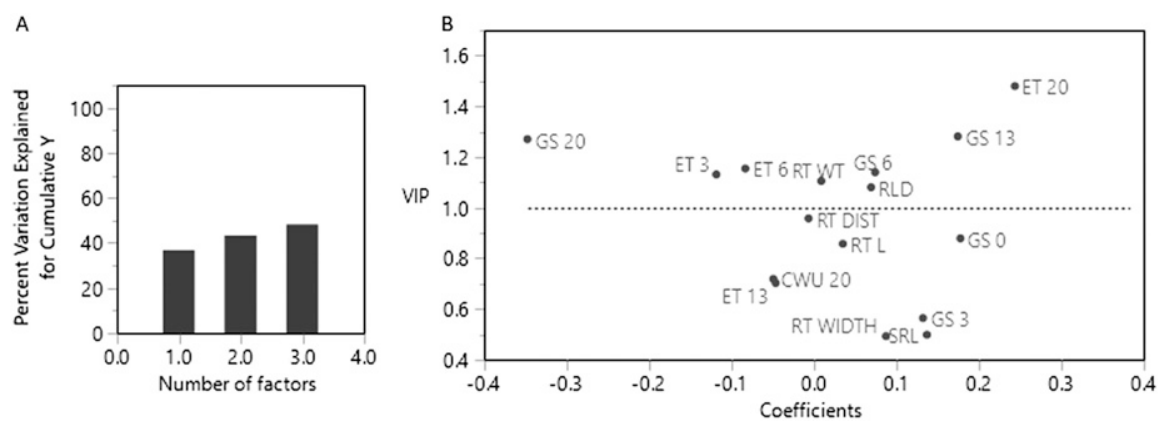

Fig. 3. Partial least-squares regression results for a model determining which drought avoidance trait explains variation in relative water content including $(\mathbf{A})$ percentage variation explained in relative water content for each factor and (B) a scaled coefficients-by-variable importance in projection (VIP) plot, with the VIP threshold set to 1.0. GS = stomatal conductance; ET = evapotranspiration; RT WT = root weight; RLD = root length density; RT DIST = root distribution; RT L = root length; CWU = cumulative water use; RT WIDTH = root width; SRL = specific root length. The number after the abbreviation represents the number of days of drought corresponding to those measures.

least-squares regression model, it is worth noting that $g_{\mathrm{S}}$ is not only affected by guard cell control of stomatal aperture, but also plant water status and hydraulic conductance throughout the plant. Signals from roots, as well as the roots ability to continue to supply water to leaf tissues, may ultimately affect measured conductance rates.

Rooting traits also differed significantly among genotypes in this study. Root development may differ both within and among species, affecting the amount and distributions of roots throughout the soil profile (Fuentealba et al., 2015). Previous research found differences in rooting characteristics among 25 zoysiagrasses, with root depth and numbers of roots deeper in the soil found to correlate significantly with drought performance based on percentage green cover (Marcum et al., 1995). Another study that also looked at rooting characteristic of wellwatered plants in greenhouse conditions, and then compared those results to field conditions, also found that RLD and root biomass from the middle and lower soil profile were positive predictors of drought performance, whereas shallow-rooted plants that had much of their roots in the upper soil profile correlated negatively with drought performance (Christensen et al., 2017). Although in the current study no single root trait accounted for drought avoidance, differences in rooting characteristics can help explain some of the results of individual genotypes, as well as account for differences in transpiration. '09-TZ-53-20' produced the least amount of roots by weight, and more than $85 \%$ of them were in the top $50 \%$ of the soil profile. Reduced rooting capacity most likely resulted in the inability to maintain water uptake and resulted in leaf dehydration in this genotype. This further supports that the interaction between below- and aboveground tissues must be considered to understand plant potential for drought avoidance.

A significant correlation was found between total root biomass and cumulative water use, and it may help explain some of the results found in this study. 'Meyer' is generally not a top performer compared with other warm-season grasses during drought trials, and 'Palisades' is considered a much more drought-tolerant variety, which requires less water (Carrow, 1996b; White et al., 1993). In the current study, 'Palisades' had the greatest root development, but also used water the quickest, whereas 'Meyer' had relatively little total root biomass but lower ET rates, which may account for its performance in this study. 'Palisades' may rely on more extensive root systems to maintain quality during water-limited environments, similar to the proposed mechanism in tall fescue (Fescue arundinacae) (Ervin and Koski, 1998), and may explain in part the lower supplemental irrigation requirements found in 'Palisades' compared with other cultivars under field conditions (White et al., 1993). In addition, the relatively poor performance of 'Meyer' in some studies may be the result of low tolerance to edaphic stresses such as soil $\mathrm{pH}$, limiting the production of productive root systems in certain environments (Carrow, 1996b). Furthermore, limitations of controlled-environment pot studies compared with field trials is important to remember, and likely influenced the results of this study. Genotypes with greater SRL, RLD, and root biomass deeper in the soil (such as 'Palisades'), which may not have been the best genotypes in this study, could perform better under field conditions or in soils with greater waterholding capacity. The correlations between water use and RLD further demonstrate that root amounts and depth are both important factors that determine access to soil-available water. '15-TZ-11777' was also in the top statistical grouping for both maximum root length and RLD, indicating that it may be possible to have genotypes that combine extensive rooting and stomatal regulation to maintain quality during drought periods. Screening zoysiagrass genotypes for traits such as maximum rooting depth and RLD in the field would still be useful to improve drought tolerance in the future.

In summary, a range in drought avoidance was found among zoysiagrass genotypes, with experimental genotypes '15-TZ-11777', 'DR-113' and '09-TZ-54-09' maintaining the greatest quality and tissue hydration, whereas '09-TZ-113' was consistently the poorest performer. These differences are the result of the combination of several traits, including belowground root traits such as RLD, and total root biomass, as well as aboveground traits controlling ET from the turf canopy. Plants that were able to regulate their water use through these traits by controlling water uptake from the soil and the subsequent loss to the atmosphere through stomata maintained leaf hydration status better than those plants that were unable to do so. The ability to reduce water use quickly and maintain stable transpiration rates were associated with drought avoidance in this study. Rooting traits were also important, as demonstrated by the poor performance of '09-TZ-53-20'. In the current study, extensive rooting alone did not lead to superior drought performance, although a strong relationship between extensive root systems and water extraction was seen. The ability to exploit large volumes of soil to extract water, as well as the ability to reduce transpiration quickly may be the best combination to improve drought performance. Experimental lines such as '09-TZ-11777' and 'DR-113' demonstrated combinations of important above- and belowground drought avoidance traits not seen in commercial cultivars. Additional facets of drought tolerance such as osmotic adjustment, changes in leaf water potential, carbon partitioning, or aquaporin activity need to be explored to grasp more fully the development of drought symptoms in turfgrasses (Huang et al., 2014; White et al., 2001). Understanding drought-related traits and their regulation, particularly in field conditions, will be essential in developing improved cultivars of turfgrasses that need less water. 


\section{Literature Cited}

Anderson, V.J. and D.D. Briske. 1990. Stomatal distribution, density and conductance of three perennial grasses native to the southern true prairie of Texas. Amer. Midl. Nat. 123(1):152159.

Barrs, H.D. and P.E. Weatherley. 1962. A reexamination of the relative turgidity technique for estimating water deficits in leaves. Austral. J. Biol. Sci. 15(3):413-428.

Carrow, R.N. 1996a. Drought avoidance characteristics of diverse tall fescue cultivars. Crop Sci. 36(2):371-377.

Carrow, R.N. 1996b. Drought resistance aspects of turfgrasses in the southeast: Root-shoot responses. Crop Sci. 36(3):687-694.

Cathey, S.E., J.K. Kruse, T.R. Sinclair, and M.D. Dukes. 2013. Transpiration and visual appearance of warm season turfgrasses during soil drying. Environ. Exp. Bot. 89:36-43.

Christensen, C.T., J. Zhang, K.E. Kenworthy, J. Erickson, J. Kruse, and B. Schwartz. 2017. Classification of zoysiagrass genotypes on rooting capacity and associated performance during drought. Intl. Turfgrass Soc. Res. J. 13(1): 410-420.

Colmer, T.D. and L. Barton. 2017. A review of warm-season turfgrass evapotranspiration, responses to deficit irrigation, and drought resistance. Crop Sci. 57(Suppl. 1):S98-S110.

Comas, L.H., S.R. Becker, V.M.V. Cruz, P.F. Byrne, and D.A. Dierig. 2013. Root traits contributing to plant productivity under drought. Front. Plant Sci. 4. doi: 10.3389/ fpls.2013.00442.

Ervin, E.H. and A.J. Koski. 1998. Drought avoidance aspects and crop coefficients of Kentucky bluegrass and tall fescue turfs in the semiarid west. Crop Sci. 38(3):788-795.

Fuentealba, M.P., J. Zhang, K.E. Kenworthy, J.E. Erickson, J. Kruse, and L.E. Trenholm. 2015. Root development and profile characteristics of bermudagrass and zoysiagrass. HortScience 50:1429-1434.

Fuentealba, M.P., J. Zhang, K. Kenworthy, J. Erickson, J. Kruse, and L. Trenholm. 2016. Transpiration responses of warm-season turfgrass in relation to progressive soil drying. Scientia Hort. 198:249-253.

Galkovskyi, T., Y. Mileyko, A. Bucksch, B. Moore, O. Symonova, C.A. Price, C.N. Topp, A.S. Iyer-Pascuzzi, P.R. Zurek, S. Fang, J. Harer, P.N. Benfey, and J.S. Weitz. 2012.
GiA Roots: Software for the high throughput analysis of plant root system architecture. BMC Plant Biol. 12:116.

Gowda, V.R.P., A. Henry, A. Yamauchi, H.E. Shashidhar, and R. Serraj. 2011. Root biology and genetic improvement for drought avoidance in rice. Field Crops Res. 122(1):1-13.

Green, R.L., S.I. Sifers, C.E. Atkins, and J.B. Beard. 1991. Evapotranspiration rates of eleven zoysia genotypes. HortScience 26:264-266.

Hilu, K.W. and J.L. Randall. 1984. Convenient method for studying grass leaf epidermis. Taxon 33(3):413-415.

Huang, B., M. DaCosta, and Y. Jiang. 2014 Research advances in mechanisms of turfgrass tolerance to abiotic stresses: From physiology to molecular biology. Crit. Rev. Plant Sci. 33(2-3):141-189.

Huang, B., R.R. Duncan, and R.N. Carrow. 1997. Drought-resistance mechanisms of seven warm-season turfgrasses under surface soil drying: I. Shoot response. Crop Sci. 37(6):18581863.

Jones, H.G. 1998. Stomatal control of photosynthesis and transpiration. J. Expt. Bot. 49:387398.

Jones, M.M., N.C. Turner, and C.B. Osmond. 1981. Mechanisms of drought resistance, p. 15-37. In: L.G. Paleg and D. Aspinall (eds.). The physiology and biochemistry of drought resistance in plants. Academic Press, New York, NY.

Kashiwagi, J., L. Krishnamurthy, H.D. Upadhyaya, H. Krishna, S. Chandra, V. Vadez, and R. Serraj. 2005. Genetic variability of droughtavoidance root traits in the mini-core germplasm collection of chickpea (Cicer arietinum L.). Euphytica 146(3):213-222.

Kim, K.S. and J.B. Beard. 1988. Comparative turfgrass evapotranspiration rates and associated plant morphological characteristics. Crop Sci. 28(2):328-331.

Krans, J.V. and K. Morris. 2007. Determining a profile of protocols and standards used in the visual field assessment of turfgrasses: A survey of national turfgrass evaluation program-sponsored university scientists. Appl. Turfgrass Sci 4(1). doi: 10.1094/ATS-20071130-01-TT.

Marcum, K.B., M.C. Engelke, S.J. Morton, and R.H. White. 1995. Rooting characteristics and associated drought resistance of zoysiagrasses. Agron. J. 87(3):534-538.
O’Toole, J.C., R.T. Cruz, and T.N. Singh. 1979. Leaf rolling and transpiration. Plant Sci. Lett. 16(1):111-114.

Patton, A.J. 2009. Selecting zoysiagrass cultivars: Turfgrass quality, growth, pest and environmental stress tolerance. Appl. Turfgrass Sci. 6(1). doi: 10.1094/ATS-2009-1019-01-MG.

Popova, L.P., W.H. Outlaw, Jr., K. Aghoram, and D.R.C. Hite. 2000. Abscisic acid: An intraleaf water-stress signal. Physiol. Plant. 108(4):376381.

Qian, Y.L. and M.C. Engelke. 1999. Performance of five turfgrasses under linear gradient irrigation. HortScience 34:893-896.

Qian, Y.L., J.D. Fry, and W.S. Upham. 1997. Rooting and drought avoidance of warmseason turfgrasses and tall fescue in Kansas. Crop Sci. 37(3):905-910.

Schnell, R.W., D.M. Vietor, R.H. White, T.L. Provin, and C.L. Munster. 2009. Effects of composted biosolids and nitrogen on turfgrass establishment, sod properties, and nutrient export at harvest. HortScience 44:1746-1750.

Schroeder, J.I., G.J. Allen, V. Hugouvieux, J.M. Kwak, and D. Waner. 2001. Guard cell signal transduction. Annu. Rev. Plant Physiol. Plant Mol. Biol. 52(1):627-658.

Sperry, J.S., U.G. Hacke, R. Oren, and J.P. Comstock. 2002. Water deficits and hydraulic limits to leaf water supply. Plant Cell Environ. 25(2):251-263.

Wherley, B., J. Heitholt, A. Chandra, and P. Skulkaew. 2014. Supplemental irrigation requirements of zoysiagrass and bermudagrass cultivars. Crop Sci. 54(4):1823-1831.

Wherley, B.G. and T.R. Sinclair. 2009. Differential sensitivity of $\mathrm{C} 3$ and $\mathrm{C} 4$ turfgrass species to increasing atmospheric vapor pressure deficit. Environ. Exp. Bot. 67(2):372-376.

White, R.H., M.C. Engelke, S.J. Anderson, B.A. Ruemmele, K.B. Marcum, and G.R. Taylor. 2001. Zoysiagrass water relations. Crop Sci. 41:133-138.

White, R.H., M.C. Engelke, S.J. Morton, and B.A. Ruemmele. 1993. Irrigation water requirement of Zoysiagrass. Intl. Turfgrass Soc. Res. J. 7:587-593.

Zhang, J., K. Kenworthy, J.B. Unruh, B. Poudel, J.E. Erickson, D. Rowland, and J. Kruse. 2017. Physiological responses to soil drying by warm-season turfgrass species. Crop Sci. 57(Suppl. 1):S111-S118. 